extraneous sources of acid or alkali. This factor was initially one of the most difficult to control until a stringent washing technique was introduced. Use of a McCartney bottle for the $5-\mathrm{ml}$ test mixture ensures that sufficient surface area is available for aeration and accommodates gas released during incubation.

Since tests established that 5-FC could be autoclaved without affecting its antifungal activity, all standards, control sera, and test sera were autoclaved before incorporation in the assay mixture. This had the effect of driving off dissolved blood gases thus eliminating minor differences in starting $\mathrm{pH}$ which might occur from this cause. Furthermore, as protein is denatured the effect of specific or non-specific antibodies which may be present in test serum and which could interfere with growth of the organism and acid production is reduced.

Provided the conditions of the assay are observed, rapid reproducible estimation of $5-\mathrm{FC}$ in serum and urine can be obtained with an accuracy of about $\pm 5 \%$. The method is an improvement on the currently available assay techniques and should be applicable to the measurement of other antifungal agents.

D. J. S. and J. K. D. were supported by a grant from the Felton Bequest. Mrs. M. Henning and Mr. K. Wadsworth provided valuable technical help.

\section{References}

Faine, S., and Knight, D. C. (1968). Lancet, 2, 375.

Koechlin, B. A., Rubio, F., Palmer, S., Gabriel, T., and Duschinsky, R.

(1966). Biochemical Pharmacology, 15, 435.
Shadomy, S. (1969). Applied Microbiology, 17, 871.

Wade, D. N., and Sudlow, G. (1972). Australian and New Zealand fournal of Medicine, 2, 153.

\title{
Use of 5-Fluorocytosine in Patients with Impaired Renal Function
}

\author{
J. K. DAWBORN, M. D. PAGE, D. J. SCHIAVONE
}

British Medical fournal, 1973, 4, 382-384

\section{Summary}

The plasma level and elimination of 5-fluorocytosine (5-FC) was measured in normal subjects and patients with impaired renal function. Prolongation of the halflife of the drug in renal failure has been confirmed. Renal clearance of 5-FC was about $75 \%$ of the creatinine clearance and a corresponding modification of drug dosage should be made in patients with renal insufficiency.

\section{Introduction}

5-Fluorocytosine (5-FC) is an effective oral therapeutic agent for the treatment of fungal infections due to sensitive strains of Candida albicans, Cryptococcus neoformans, and Aspergillus fumigatus. The drug is not metabolized in man but is excreted almost entirely by the kidney (Koechlin et al., 1966; Wade and Sudlow, 1972). The recommended dose range in persons with normal kidney function is $0 \cdot 1-0 \cdot 2 \mathrm{~g} / \mathrm{kg} /$ day but this has not been firmly established and there is little information about blood and urine levels of the drug. The development of a rapid microbiological assay (Schiavone et al., 1973) has allowed us to make observations on the serum levels and urinary excretion of 5-FC in normal subjects and in patients with impaired renal function.

\section{Materials and Methods}

Twenty subjects were studied of whom five had normal renal

\footnotetext{
University of Melbourne, Austin Hospital, Heidelberg 3084, Victoria, Australia

J. K. DAWBORN, PH.D., F.R.A.C.P., Senior Renal Physician

M. D. PAGE, M.SC., Graduate Research Assistant, Department of

D. J. SCHIAVONE, M.B., F.R.C.P.A. Senior Lecturer in Medical Microbiology
}

function, four were anephric, and 11 had varying degrees of renal impairment (see table I). Each person was studied after an oral dose of $2 \mathrm{~g}$ 5-FC. Serum and urine 5-FC measurements were made as previously described (Schiavone et al., 1973). Serum levels of 5-FC were measured often over 12 hours in normal subjects and for up to 48 hours in patients with renal failure. In most subjects accurately timed urine collections were also obtained for calculation of 5-FC and creatinine clearances, and in four patients the removal of 5-FC was studied during haemodialysis.

The serum 5-FC levels (log scale) were plotted on semilogarithmic paper against time. After the first four hours the fall in serum 5-FC was about linear in all subjects and the biological half life $\left(t \frac{1}{2}\right)$ of the drug was calculated from the linear regression of $\log$ serum $5-\mathrm{FC}$ against time. The volume of distribution of the drug was calculated by extrapolating this curve to zero time and dividing the total dose by the derived value for the serum $5-\mathrm{FC}$ concentration at zero time. Clearances of 5-FC and creatinine were determined from a timed urine collection (usually the four- to eight-hour period after the dose) and the mean serum concentration for the collection period.

The assumption was made that the drug was not bound to protein (Wade and Sudlow, 1972). Clearance of creatinine and 5-FC by dialysis was calculated according to the formula:

$$
\text { dialysis clearance }=Q \quad \frac{(\mathrm{A}-\mathrm{V})}{\mathrm{A}}
$$

where $Q$ was the blood flow rate through the dialyser and $A$ and $\mathrm{V}$ were the serum levels of 5-FC or of creatinine respectively entering and leaving the dialyser. Creatinine was measured with a Technicon AutoAnalyzer. Statistical analyses were carried out with a Hewlett Packard computer and programs.

\section{Results}

These are summarized in table I. Serum 5-FC levels are compared in fig. 1 over 12 hours after an oral dose of $2 \mathrm{~g} \mathrm{5-FC} \mathrm{in}$ five normal subjects and in five patients with severe terminal renal failure (creatinine clearance $<3 \mathrm{ml} / \mathrm{min}$ ). When renal function was normal a mean peak level ( \pm S.E. of mean) of 
TABLE I-Renal Function, Serum 5-FC Half Life in 16 Patients with Different Levels of Renal Function. Details of Four Anephric Subjects have Not been Included

\begin{tabular}{|c|c|c|c|c|c|c|c|c|c|}
\hline \multirow[t]{2}{*}{ Body Weight } & \multirow[t]{2}{*}{$\begin{array}{c}\text { Plasma } \\
\text { Creatinine } \\
\text { (mg/100 ml) }\end{array}$} & \multirow[t]{2}{*}{$\begin{array}{l}\text { Creatinine } \\
\text { Clearance } \\
(\mathrm{ml} / \mathrm{min})\end{array}$} & \multicolumn{2}{|c|}{$\underset{(\mu \mathrm{g} / \mathrm{ml})}{\operatorname{Serum}} 5-\mathrm{FC}$} & \multirow[t]{2}{*}{$\begin{array}{c}\text { Urine } 5-\mathrm{FC} \\
4-8 \mathrm{hr} \\
(\mu \mathrm{g} / \mathrm{ml})\end{array}$} & \multirow[t]{2}{*}{$\begin{array}{c}\text { 5-FC } \\
\text { Clearance } \\
(\mathrm{ml} / \mathrm{min})\end{array}$} & \multirow{2}{*}{$\begin{array}{c}\begin{array}{c}\text { Clearance } \\
5-\mathrm{FC}\end{array} \\
\text { Creatinine }\end{array}$} & \multirow{2}{*}{$\underset{\text { (hours) }}{\text { Half Life }}$} & \multirow{2}{*}{$\begin{array}{c}\text { 5-FC Volume } \\
\text { Distribution } \\
(\mathrm{ml} \mathrm{kg})\end{array}$} \\
\hline & & & $8 \mathrm{hr}$ & $24 \mathrm{hr}$ & & & & & \\
\hline $\begin{array}{l}70 \\
67 \\
63 \\
75 \\
99 \\
47 \\
68 \\
58 \\
55 \\
60 \\
69 \\
42 \\
93 \\
61 \\
51 \\
72\end{array}$ & $\begin{array}{r}1 \cdot 1 \\
1 \cdot 1 \\
1 \cdot 1 \\
1 \cdot 2 \\
1 \cdot 2 \\
1 \cdot 2 \\
2 \cdot 2 \\
2 \cdot 2 \\
2 \cdot 4 \\
3 \cdot 5 \\
4 \cdot 4 \\
5 \cdot 4 \\
7 \cdot 0 \\
9 \cdot 3 \\
11 \cdot 0 \\
15 \cdot 0\end{array}$ & $\begin{array}{r}148 \\
145 \\
127 \\
110 \\
165 \\
48 \\
46 \\
42 \\
20 \\
16 \\
15 \\
10 \\
12 \\
9 \\
4 \\
4\end{array}$ & $\begin{array}{l}13 \\
17 \\
17 \\
17 \\
16 \\
49 \\
41 \\
37 \\
46 \\
52 \\
40 \\
65 \\
32 \\
45 \\
54 \\
44\end{array}$ & $\begin{array}{r}0 \\
0 \\
0 \\
0 \\
0 \\
18 \\
18 \\
30 \\
27 \\
38 \\
22 \\
37 \\
46 \\
37\end{array}$ & $\begin{array}{r}2,350 \\
2,240 \\
640 \\
1,920 \\
2,370 \\
1,600 \\
1,480 \\
2,560 \\
450 \\
339 \\
450 \\
165 \\
280 \\
175 \\
145 \\
308\end{array}$ & $\begin{array}{c}116 \\
83 \\
113 \\
103 \\
117 \\
29 \\
27 \\
25 \\
9 \cdot 3 \\
11 \\
18 \\
6.0 \\
14.5 \\
6.4 \\
2.8 \\
<1.0\end{array}$ & $\begin{array}{r}.78 \\
.57 \\
.89 \\
.93 \\
.71 \\
.60 \\
.59 \\
.60 \\
.46 \\
.69 \\
1.20 \\
.60 \\
1.21 \\
.71 \\
.76 \\
\end{array}$ & $\begin{array}{r}4 \cdot 7 \\
4 \cdot 2 \\
4 \cdot 9 \\
7 \cdot 4 \\
6 \cdot 7 \\
18 \cdot 2 \\
18 \cdot 2 \\
13 \cdot 7 \\
15 \cdot 1 \\
11 \cdot 3 \\
27 \cdot 4 \\
27 \cdot 3 \\
50 \cdot 2 \\
60 \\
75 \\
>100\end{array}$ & $\begin{array}{l}620 \\
530 \\
600 \\
670 \\
579 \\
584 \\
575 \\
504 \\
433 \\
565 \\
483 \\
614 \\
650 \\
661 \\
-\end{array}$ \\
\hline
\end{tabular}

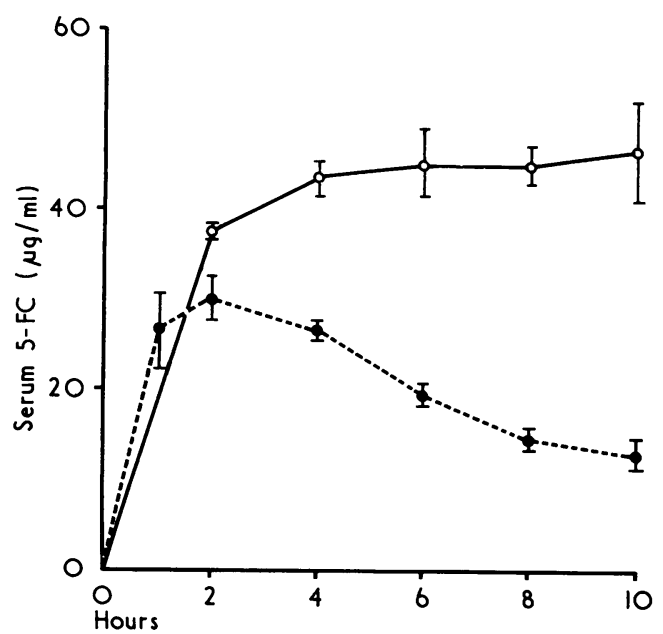

FIG. 1-Comparison of mean serial plasma levels ( \pm S.E. of mean) of 5-FC after an oral dose of $2 \mathrm{~g}$ in five normal subjects $(O)$ and five patients with terminal renal failure $(\mathbf{O})$.

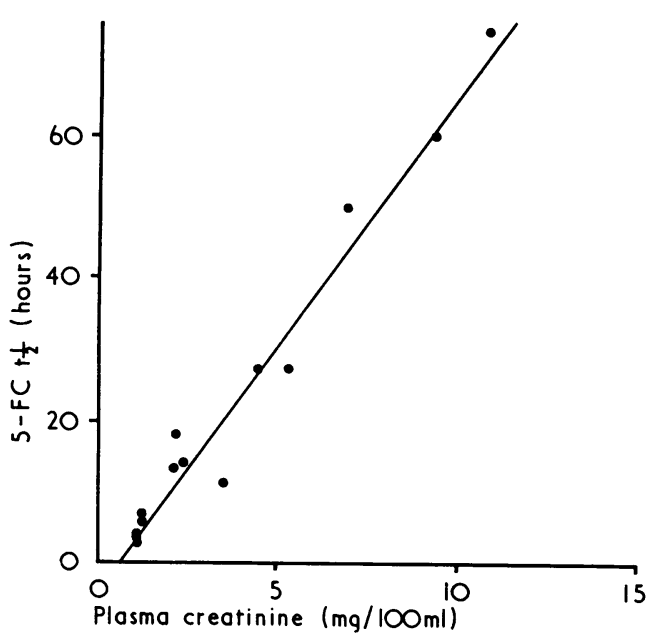

FIG. 2-Relation between $t^{\frac{1}{2}} 5-\mathrm{FC}$ and plasma creatinine concentration.

$30 \pm 2 \cdot 8 \mu \mathrm{g} / \mathrm{ml}$ was reached by two hours after which there was a gradual fall. Altogether 30 to $50 \%$ of the administered dose had been excreted after eight hours and 63 to $84 \%$ by 24 hours. In the five patients with terminal renal failure the serum 5-FC concentration continued to rise for four to six hours. The peak level was $48 \pm 4 \cdot 7 \mu \mathrm{g} / \mathrm{ml}$ and high levels were still present after 24 hours $(31 \pm 3.7 \mu \mathrm{g} / \mathrm{ml})$. The excretion of $5-\mathrm{FC}$ was pro- portionately reduced in patients with less severe renal impairment and an appreciable drug level was still present at 24 hours (table I). Urine levels of 5-FC diminished with decreasing renal function but always far exceeded peak serum levels.

The $t \frac{1}{2}$ of 5-FC was markedly prolonged in patients with renal insufficiency. The mean $t \frac{1}{2}$ ( \pm S.E. of mean) in five normal subjects was $5.3 \pm 0.7$ hours compared with 60 hours in a patient with severe renal impairment (creatinine clearance of $9 \mathrm{ml} / \mathrm{min}$ ). Prolongation of the $t_{2} \frac{1}{2}$ of other subjects was related to the degree of renal function impairment (see table I). The relation between 5-FC $t \frac{1}{2}$ and serum creatinine concentration (fig. 2) was given by

$$
\begin{gathered}
\mathrm{y}=6.8 \chi-2.7 \text { (coefficient of correlation } 0.98 \text { ) where } \\
\mathrm{y}=\mathrm{t} \frac{1}{2} 5-\mathrm{FC} \text { in hours and } \chi=\text { plasma } \\
\text { creatinine concentration in } \mathrm{mg} / 100 \mathrm{ml} \text {. }
\end{gathered}
$$

The $t \frac{1}{2}$ of $5-F C$ was about six times the serum creatinine in $\mathrm{mg} / 100 \mathrm{ml}$. The volume of distribution of $5-\mathrm{FC}$ had a mean value ( \pm S.E. of mean) of $569 \pm 19 \mathrm{ml} / \mathrm{kg}$. There was a good correlation between 5-FC clearance and creatinine clearance, 5 -FC clearance being about $75 \%$ of the creatinine clearance (fig. 3).

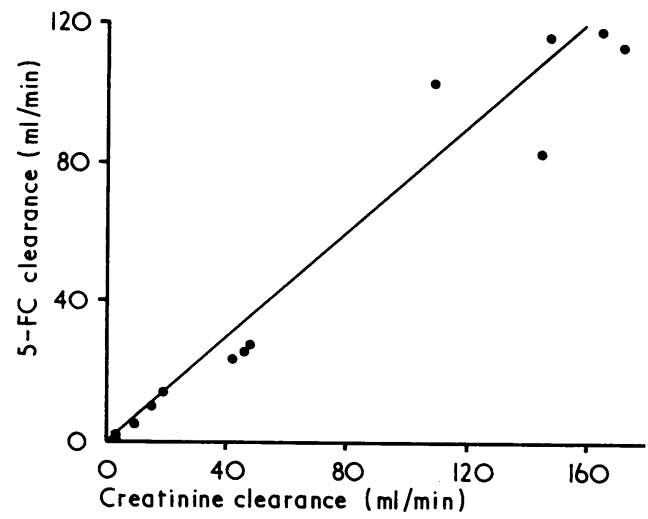

FIG. 3-Correlation between clearances of 5-FC $(y)$ and creatinine $(x) . y=0.75 x-0.27$ (co-efficient of correla-
tion 0.97 ).

TABLE II-Clearance of 5-FC and Creatinine across Flat-plate and Hollow Fibre Dialysers

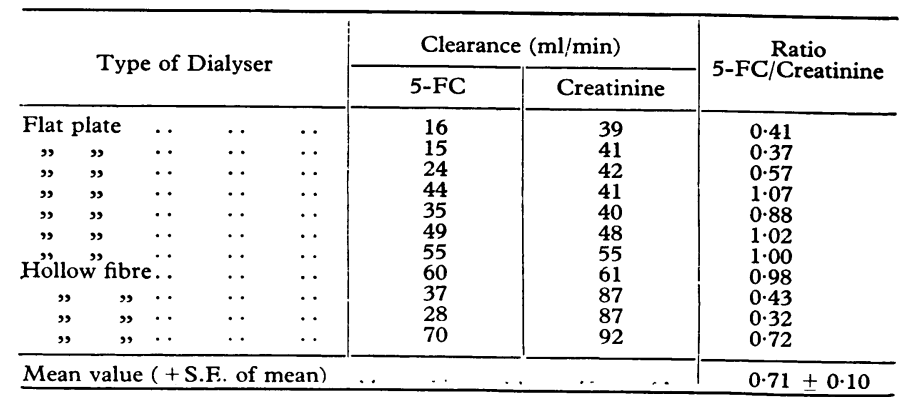


In patients undergoing haemodialysis the removal of 5-FC and creatinine were compared. Eleven observations were made in four patients using either a disposable flat plate dialyser or hollow fibre kidney. These results are shown in table II. Clearance values for creatinine were more consistent than those for 5-FC. The mean value ( \pm S.E. of mean) for $5-F C /$ creatinine clearance across the dialysers was $0.71 \pm 0 \cdot 10$.

\section{Discussion}

These results confirm and extend previous observations by Koechlin et al. (1966) and Wade and Sudlow (1972) which indicate that the excretion of 5-FC is almost entirely via the kidney. Results of 5-FC half life and renal clearance estimations for a group of patients with renal failure are comparable to those predicted by Wade and Sudlow (1972) on the basis of kinetic studies of 5-FC elimination in normal subjects using radioactive techniques. Their figures predict $t \frac{1}{2}$ values of 13 and 32 hours for a 70-kg man with a glomerular filtration rate of 50 or 20 $\mathrm{ml} / \mathrm{min}$ respectively. These results compare well with values derived experimentally in this study where $t \frac{1}{2}$ values of 11 hours and of 31 hours would be expected from subjects with plasma creatinine concentrations of $2 \mathrm{mg} / 100 \mathrm{ml}$ and of $5 \mathrm{mg} / 100 \mathrm{ml}$ respectively (fig. 3 ).

5-FC is widely distributed throughout the body with a volume of distribution $(569 \pm 19 \mathrm{ml} / \mathrm{kg}$ ) close to the estimated total body water. From this a serum value of about $50 \mu \mathrm{g} / \mathrm{kg}$ would be expected in a 70-kg anephric subject after a 2-g dose. In normal subjects, owing to prompt excretion of the drug, the mean peak serum level ( $t$ S.E. of mean) was lower $(30 \pm$ $2 \cdot 8 \mu \mathrm{g} / \mathrm{ml}$ ) and was reached by two hours. This value is about equal to the dose given in $\mathrm{mg} / \mathrm{kg}$ (Wade and Sudlow, 1972). The maximum serum level observed in anephric subjects was $50 \%$ higher $(48 \pm 4.7 \mu \mathrm{g} / \mathrm{ml})$ than in normal subjects and was delayed until four to six hours. In subjects with diminished renal function serum 5-FC levels were also increased in relation to the degree of impairment. Thus some modification of the initial loading dose of 5-FC may be necessary in patients with severe renal failure.

Knowledge that the biological half life of the drug is about six times the serum creatinine concentration in $\mathrm{mg} / 100 \mathrm{ml}$ (see table I) has practical application; thus a normal patient with normal serum creatinine of $1 \mathrm{mg} / 100 \mathrm{ml}$ should have the initial dose repeated six-hourly, but a patient with a serum creatinine of $2 \mathrm{mg} / 100 \mathrm{ml}$ would require 12 -hourly dosage. In patients with severe renal impairment 24 -to 48 -hour dosage intervals may be indicated.

The urinary level of 5-FC in normal subjects was several hundred times that in the blood, whereas patients with reduced renal function had much lower urinary 5-FC concentrations. The high urine levels obtained make 5-FC an ideal drug for the treatment of urinary candidiasis.

In patients with impaired renal function it is necessary to monitor the serum 5-FC levels regularly to detect rising serum values due to diminished drug excretion. Regular serum 5-FC monitoring is also advisable where renal function is alteringfor instance, during recovery from acute renal failure where adjustment of dosage intervals will be required to ensure that satisfactory serum levels are maintained when urine excretion increases as a result of improved renal function. In patients with normal renal function but with serious fungal infection maximal non-toxic serum levels are desirable. Frequent monitoring of serum levels are again required and the sensitivity of the organism should be determined. The rapid microbiological technique used in this study ensures that repeated measurements of serum and urine 5-FC can be carried out rapidly, allowing continual adjustment of 5-FC dosage to maintain maximum effective therapeutic non-toxic levels of the drug.

J. K. D. and D. J. S. were supported by a grant from the Felton Bequest. We are grateful to Dr. G. Pattison, Director of Biochemistry, Austin Hospital, for creatinine estimations and to Roche Products, Australia, Ltd., for supplies of 5-fluorocytosine.

\section{References}

Koechlin, B. A., Rubio, F., Palmer, S., Gabriel, T., and Duschinsky, R. (1966). Biochemical Pharmacology, 15, 435.

Schiavone, D. J., Page, M., and Dawborn, J. K. (1973). British Medical

fournal, 4, 380 .
Wade, D. N., and Sudlow, G. (1972). Australian and New Zealand fournal of Medicine, 2, 153. 